\title{
Machtgefühle im Wandel der Versionen
}
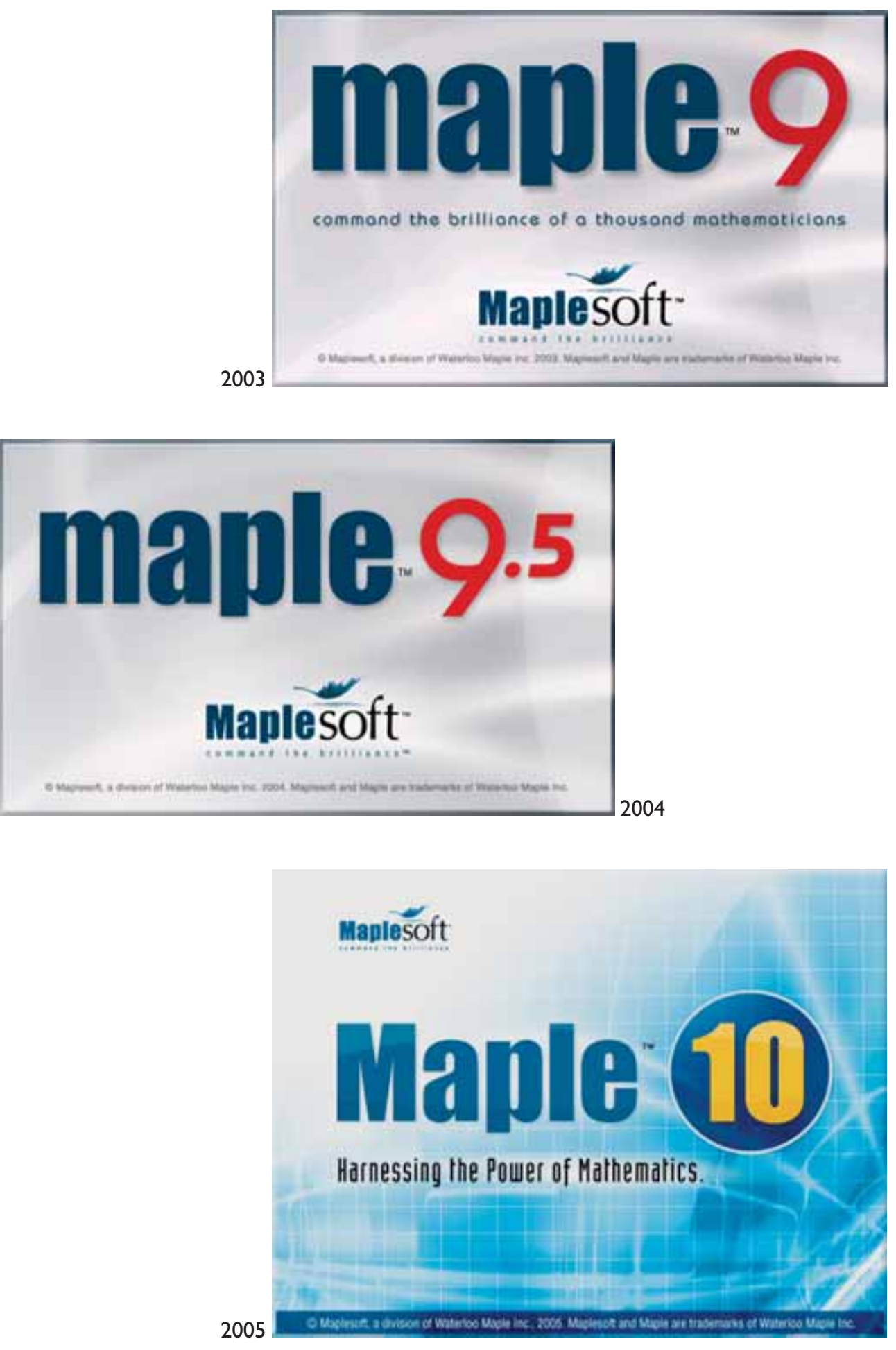